\title{
Methodism and transformation in South Africa: 20 years of constitutional democracy
}

\begin{tabular}{|c|c|}
\hline \multicolumn{2}{|c|}{$\begin{array}{l}\text { Author: } \\
\text { Wessel Bentley }{ }^{1}\end{array}$} \\
\hline \multicolumn{2}{|c|}{$\begin{array}{l}\text { Affiliation: } \\
{ }^{1} \text { Research Institute for } \\
\text { Theology and Religion, } \\
\text { University of South Africa, } \\
\text { South Africa }\end{array}$} \\
\hline \multicolumn{2}{|c|}{$\begin{array}{l}\text { Note: } \\
\text { This article was originally } \\
\text { presented as a paper at } \\
\text { the } 13 \text { th Oxford Institute } \\
\text { for Methodist Theological } \\
\text { Studies, } 12-19 \text { August } 2013 \text {. }\end{array}$} \\
\hline \multicolumn{2}{|c|}{$\begin{array}{l}\text { Correspondence to: } \\
\text { Wessel Bentley }\end{array}$} \\
\hline \multicolumn{2}{|c|}{$\begin{array}{l}\text { Email: } \\
\text { bentlw1@unisa.ac.za }\end{array}$} \\
\hline \multicolumn{2}{|c|}{$\begin{array}{l}\text { Postal address: } \\
\text { PO Box } 905-1304, \\
\text { Garsfontein 0042, } \\
\text { South Africa }\end{array}$} \\
\hline \multicolumn{2}{|c|}{$\begin{array}{l}\text { Dates: } \\
\text { Received: } 02 \text { Apr. } 2014 \\
\text { Accepted: } 29 \text { July } 2014 \\
\text { Published: } 20 \text { Nov. } 2014\end{array}$} \\
\hline \multicolumn{2}{|c|}{$\begin{array}{l}\text { How to cite this article: } \\
\text { Bentley, W., 2014, } \\
\text { 'Methodism and } \\
\text { transformation in South } \\
\text { Africa: } 20 \text { years of } \\
\text { constitutional democracy', } \\
\text { HTS Teologiese Studies/ } \\
\text { Theological Studies } 70(1) \text {, } \\
\text { Art. \#2673, } 8 \text { pages. http:// } \\
\text { dx.doi.org/10.4102/hts. } \\
\text { v70i1.2673 }\end{array}$} \\
\hline \multicolumn{2}{|c|}{$\begin{array}{l}\text { Copyright: } \\
\text { (C) 2014. The Authors. } \\
\text { Licensee: AOSIS } \\
\text { OpenJournals. This wo } \\
\text { is licensed under the } \\
\text { Creative Commons } \\
\text { Attribution License. }\end{array}$} \\
\hline \multicolumn{2}{|l|}{ Read online: } \\
\hline 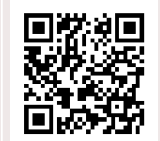 & $\begin{array}{l}\text { Scan this QR } \\
\text { code with your } \\
\text { smart phone or } \\
\text { mobile device } \\
\text { to read online. }\end{array}$ \\
\hline
\end{tabular}

It has been two decades since South Africa became a constitutional democracy. The transition of power in this country has not necessarily meant that the majority of South Africans have experienced a transformed life. The incessant experience of poverty, poor service delivery and lack of political will to facilitate change is leading to violent protest action. This article investigates the progression in the Methodist Church of Southern Africa's theological understanding of its role in being an agent of change in local communities. It does so by reflecting on the Church's place in the current political context, its programmes and recent initiatives in its mission-based focus.

\section{Introduction}

1994 will be remembered in South African history as the year of liberation. For the first time, South Africans of all races were able to vote during the national elections. The world held its breath as South Africans chose to comprehensively change the leadership, structure and ideological course of this country. This transition, which is taking place relatively peacefully, has been hailed by many as a miracle. I deliberately state 'is taking place' because the ideals of a new South Africa have not yet been accomplished. Shortly after the 1994 elections, several new leaders, structures and symbols were introduced to this fledgling democracy. It gained a new president in the person of Nelson Mandela, it adopted a new flag and national anthem, restructured its provinces (increasing them from four to nine) and increased the number of official languages from 2 to 11, but most importantly, it adopted a new Constitution. It is this Constitution which would outline the fabric and identity of the South African people. Much has happened in the past 20 years; advances have been made in addressing many of the structured social disparities of the past, but it must be said that transformation as a whole has been rather slow.

Although one hails advances in social redress and acknowledges that South Africa is still an economic powerhouse on the African continent, there is concern for the long-term well-being of the country. In the past decade, South Africa has seen an increase in the economic disparities between the rich and the poor. According to The World Bank, South Africa's rating on the Gini index ${ }^{1}$ was recorded as 63.14 (World Bank n.d.) in 2009. This indicates that South Africa is one of the countries with the greatest economic divide among its population. Further problems in South African society are worth noting, including the quality of education. The World Economic Forum and INSEAD have rated the level of education in South Africa as fifth lowest in the world (World Economic Forum \& INSEAD 2013:324). On the quality of mathematics and science education scale, South Africa was rated 143 out of 144 countries (World Economic Forum \& INSEAD 2013:145). This is cause for concern as developing countries need a well-equipped and competitive workforce in order to be productive in the global economy. The problems in education are further exacerbated by teacher absenteeism, teacher strikes, the lack of delivery of textbooks, and the poor conditions that exist in public schools. Further to this, the health sector is in dire straits as a result of the overwhelming need for proper health care and a lack of medical capacity. Adequate health care is difficult to achieve as there is a shortfall in infrastructure, limited resources, and insufficient availability of basic medical services. According to an independent audit of the South African health care sector, $77 \%$ of clinics lacked the presence of tracer medicines as per the applicable Essential Drugs List or formulary; the percentage for hospitals stands at $66 \%$ (Health Systems Trust 2013:39-40).

In addition, the country has seen wave after wave of government scandals ranging from misappropriation of public funds, the abuse of power for material gain, an arms deal scandal, a scandal involving the building of a presidential residence at excessive cost to the public and increasing events of police brutality. ${ }^{2}$ A current controversy involving the tolling of urban

1.On the Gini scale, 0 represents complete equality while 100 represents total economic inequality.

2.The events that unfolded at the Lonmin Platinum Mine on 16 August 2012 when 34 miners were shot and killed by police officers made headlines around the world. A commission of enquiry into these events is currently underway. 
highways is driving a wedge between civil society and those in leadership, with many unanswered questions relating to the allocation of collected revenue into the hands of foreign corporates. There is clearly an increasing public distrust of power which, in my understanding, led to a shift in voting trends during the 2014 national elections. ${ }^{3}$ Admittedly this is a rather bleak picture and it would only be natural to ask whether South Africa has a sustainable future. Without putting my head in the sand and at the risk of sounding overly optimistic, it is my contention that South Africa has the potential to regain its vision of being a nation built on the principles embodied by the iconic figure of Nelson Mandela. To achieve this would however require South Africans' commitment to and participation in social redress with faith communities like Christians playing a pivotal role.

This article explores the role of Christianity, specifically from a Methodist theological perspective, in the building of a healthier and better South Africa for all. Firstly, I will do so by sharing some comments on the role and place of the church in a secular ${ }^{4}$ constitutional democracy. Secondly, I will describe the Methodist Church of Southern Africa's understanding of mission. Thirdly, I will provide examples of how Methodism is contributing towards nation-building in South Africa.

\section{The church in a secular constitutional democracy}

There are a few questions that are raised about the South African situation with reference to Church-State relationships. Firstly, why should the church bother with becoming involved in social development? Secondly, is it not the role of politics and political systems to ensure productivity, peaceful coexistence and social harmony? Thirdly, what is the place of religion in social upliftment, but more so in the social structure of a secular democracy? These questions have been asked before in other democracies, but it is important to ask these questions from a South African perspective. One takes note of the fact that the South African contribution to this ongoing discourse may learn from other voices on this topic. The South African context is however unique; its Constitution is not a carbon copy of constitutions elsewhere and as a young democracy it needs to find its own views and perspectives on social development, religion and politics. This is an ongoing process and I do not suggest that I am able to provide adequate definitions of these notions at this time. Before I can focus on Methodism's role in particular, let me first address the question of the place of religion in the South African socio-political context.

3.The African National Congress's support declined from $65.90 \%$ in 2009 to $62.15 \%$ in 2014, while the main opposition party, the Democratic Alliance, enjoyed increased support from $16.66 \%$ in 2009 to $22.23 \%$ in 2014. Political newcomers, the Economic Freedom Fighters under the leadership of Julius Malema, showed a strong political entrance with $6.35 \%$ of the vote (Independent Electoral Commission [IEC] 2014a, 2014b).

4.The term 'secular State' is generally used to describe a State which is not governed by religious powers. Habermas and others have however drawn our attention to the difference difference between a purely secular state (which can be termed as being completely a religious and a post-secular state (which although not under the authority of religion, creates space for religion in its social framework). Where I use the phrase 'secular State', I do so with a Habermasian definition of post-secularism, but retain this phrase as it is the more common phrase used in Church-State discourse.

\section{The Church and the Constitution}

The South African Constitution makes provision for freedom of religion (South Africa 1996:5), freedom of association (South Africa 1996:18), and freedom of expression for all (South Africa 1996:16). These three rights provide the platform for the place of religion in the new South Africa. In short, these three rights afford every religion the right to exist and express itself freely in the South African context. Every person who lives within the borders of South Africa has an individual right to belong to the religion of their choice and can practice their religion under the protection of the Constitution. For some religions, this is a better position than what they experienced in the past (before and during apartheid). For Christianity it has meant having to surrender a place of privilege. From colonial times up until the end of apartheid, Christianity enjoyed a dominant and elevated position of power in society; more so than any other religion. Colonial Christian missionaries played an important part in advancing the ideals of not only their faith, but also their countries of origin. The apartheid system had strong theological backing from some Christian denominations - so much so that the political system resembled what some called a 'Reformed theocracy' (Theron 2008:236). The adoption of the South African Constitution meant that the voices of different religions now carry equal weight. Christianity is now on par with other religions, or shall we rather say that all religions are on equal footing.

Further to this, the religious perspective is now but one of many different perspectives in a secular democracy (Bentley 2013:271). The Constitution invites different sectors of society, religion included, to play a constructive role in the building of a coherent society. The South African Constitution itself does not see religion as an adversary or as a sector of society excluded from social development, but as an integral part of the whole, and therefore explicitly grants protection and freedom for the people of South Africa to exercise their religions. This right is protected as long as it does not impinge on, prohibit or negate the rights afforded to people who are of different religious convictions.

It may be asked whether it is at all possible for religions to contribute towards social upliftment within the structure of a secular State. Is it not the ideal for religions such as Christianity to have enough influence that the State becomes a religious State, functioning according to the norms and values of a particular religion? If the Church works towards the manifestation of the Kingdom of God on earth, is a secular State not the antithesis of what is hoped for? Dion Forster argues that a just secular State is in fact the ideal environment for the Church to exercise its mission (see Forster's argument in Forster 2012). He bases his argument on the teaching of Prozesky (2009) which can be summarised as follows:

1. The secular State affords freedom of religion to all whom it governs. In a religious State, faith is enforced and may be in conflict with the convictions and beliefs of some or many of its citizens. From the Christian perspective, faith is a matter of conviction and cannot be imposed. 
2. In a religious State, the relationship between religion and State is blurred and it would be difficult for religion to speak prophetically when needed. The secular State is far enough removed from religion for religions such as Christianity to engage those in power.

3. Christians are not only concerned about their own rights, but also the rights of those who belong to other faith groups and vice versa. The secular State affords the opportunity for religions to speak for each other, whereas in a religious State, one religion would have an elevated place above another.

4. In a secular State, all religions enjoy equality before the law and have similar rights. Any politico-ideological alliance between a religion and the State would create an imbalance in this context and becomes the breeding ground for religious intolerance and discrimination.

Jürgen Habermas similarly gives some helpful insights into the relationship between religion and politics in constitutional democracies. As noted in footnote 6, Habermas prefers to use the term 'post-secular State', as in his understanding a secular State refers to an a-religious form of governance and social structure, while a post-secular State affords religion a legitimate, but very defined space in society. ${ }^{5}$ To Habermas, religion is critically important in the balance of morality and ownership of a democratic system (Habermas \& Ratzinger 2010:24). First of all, he asks the question, 'Does the free, secularised State exist on the basis of normative presuppositions that it itself cannot guarantee?' (Habermas \& Ratzinger 2010:21). Habermas argues that there is a great expectation placed on secular constitutional democracies to have some form of normative structure which caters equally to the diversity of the populations which they serve. The only way in which a secular constitutional democracy can exist is for there to be ownership of the constitution through the consensus of the people (Habermas \& Ratzinger 2010:21). By default, a constitution, if agreed upon by a wide range of people with different beliefs and convictions, is a structure crafted out of the essence of these diverse beliefs. There is therefore an intrinsic relationship between a constitution and the religions it defends.

Habermas further notes that in the drawing up of constitutions, the notions of democracy and human rights are inseparable (Habermas \& Ratzinger 2010:25). The normative values as conveyed through religions are a great source of our understanding of identity, values and ideals which are foundational in concepts like human rights. This does not mean that constitutions are religious documents or that the authority constitutions have is religious. Society as a whole, by adopting a constitution, vests a twofold authority in it. First of all, a constitution implies that the State authority is 'constituted', governed by the rule of law - hence, political power is totally 'permeated by the law' as directed by the will of the people (Habermas \& Ratzinger 2010:25). Secondly, the law, although having the position and power to be exercised authoritatively (from the top down), is in fact a perception of the State). product of the citizens who through the vehicle of democracy are the authors of the law. The law, under the authority of the constitution, becomes the guide for societal well-being. When the constitution is owned by the citizens, it requires that each citizen accepts some sacrifices that promote the common interests of the population as a whole (Habermas \& Ratzinger 2010:26). Only when such a system is owned by the population and exercised in the outworking of mutual cooperation can a democracy function healthily. However, a democratic system is doomed to failure in the event of:

... the transformation of the citizens of prosperous and peaceful liberal societies into isolated monads acting on the basis of self-interest, persons who used their subjective rights only as weapons against each other. (Habermas \& Ratzinger 201037)

This is the danger facing South Africa as extreme forms of hedonistic capitalism is the cause of poor leadership being exercised and unethical decisions being made, enabling the rich to become richer at the expense of the poor. ${ }^{6}$

Because society as a whole owns and is governed by the principles of a constitution, religion has a fundamental right and responsibility to be involved in social upliftment and social justice, if for no other reason than for it to contribute to the society which affords it the freedom to exercise its convictions within the secular democratic constitutional context. The Church is not divorced from society and cannot be understood as existing in isolation from it. Society is the Church's society too (Bentley 2013:271-272); it is the context which defines it and within which it finds its mission. The constitution belongs to the Church too, and from a constitutional perspective, democracy cannot function if the Church isolates itself from society, claiming to be nothing more than a place and gathering of purely religious intent. This is in fact what the Kairos document warned against when it described the Church's pious social apathy in what it termed 'Church Theology' (Kairos Theologians 1985).

However, ask any Christian movement why they are involved in social upliftment projects and the answer quite clearly would not be: 'Because this is what the Constitution and country require of us.' For Christians, and especially Methodists, the gospel it proclaims is a social gospel. It is foundational in the expression of one's faith that there is an interaction between one's love and commitment to God and one's love for your neighbour ${ }^{7}$. I would argue that for Christians, and especially Methodists, two different callings are to be held in tension; the calling from God to act in love by serving one's neighbour and the call of the constitution to be a participant in the well-being of society. The primary locus of the Church's conviction to render social service, however, is rooted in its belief that there exists no other way to be a follower of Christ but to act in love within society. Its constitutional privilege to exercise projects of

6. Ratzinger agrees in principle with Habermas's views on the role of religion in the formation of constitutional democracies, but adds the argument that religion can become a destructive factor in the public sphere when it '...builds up false can become a destructive factor in the public sphere when it '...builds up false
universalisms, thereby leading to intolerance ...' (Habermas \& Ratzinger 2010:63).

7.Admittedly, Evangelical expressions of Christianity will argue that social upliftment is part of the Church's divine calling. The Church responds to social concerns for no other reason but its obedience to God. 
social upliftment is not only coincidental, but is subjectively the outcome of its ownership of the constitution and its contribution to it, based on its faith convictions.

Peter Storey (2004) captures the essence of this twofold act of Christian love in the following statement:

\begin{abstract}
... when a Christian prays, 'Come into my heart Lord Jesus' that prayer can never be enough. When we pray that prayer, Jesus responds, 'Can I bring my friends?' When we remind him that our intention is simply that he be our 'personal Saviour' he looks puzzled. 'I'm not sure what that means' he replies, and again asks, 'Can I bring my friends?'. We look at those clustered around him and say 'O my God, not them, please not them! They're all different colours, and their cultures are so different from mine, and they talk languages I don't understand. They come from places I don't want to go to, and some of them have done things which I was taught were not very polite and nice. Lord, do you really want me to let them into my heart too?' And he says, 'Yes'... And so we say, 'Jesus, is having all these people in my heart the only way I can have you?' And Jesus says, 'Love me, love my friends'. (p. 41)
\end{abstract}

In the secular democratic constitutional context of South Africa, the Church finds itself armed with purpose. From its perspective of conviction, its purpose is primarily to serve its Lord by loving God's people. At the same time it is afforded a legitimate place by the Constitution and people of South Africa to exercise this role for the sake of society's well-being.

\section{Methodism in South(ern) Africa and Mission}

Before I explore Methodism in the South African context, I first need to limit the scope of what I seek to discuss. In South Africa and Southern Africa there are many churches which claim Wesleyan affiliations. For purposes of this discussion, I will limit my conversation to that of the denomination called the Methodist Church of Southern Africa (MCSA). This Wesleyan group is the largest Methodist denomination in Southern Africa. As the name suggests, the MCSA does not only exist within the borders of South Africa, but the MCSA Connexion stretches into Mozambique, Lesotho, Swaziland, Botswana and Namibia. These countries, with the exception of Swaziland and Lesotho are secular constitutional democracies. In the MCSA, the greater majority of Methodists reside in South Africa, with South Africa's neighbouring countries included in Districts ${ }^{8}$ which are largely based in South Africa. ${ }^{9}$

It has been well documented how Methodism played a vital role in social formation and development in South Africa. Early missionaries established schools, built medical facilities and became pivotal diplomats in the negotiations between the original inhabitants of this land and the colonial

8.A District is an ecclesiastical term in this denomination depicting a geographical area which falls under the pastoral ministry of a Bishop.

9.It must be noted that there is a strong drive for countries outside of South Africa to rather form their own districts. The Limpopo District of the MCSA for instance is investigating the possibility of circuits in the country of Botswana to separate from the Limpopo District and to form their own District and to incorporate all the structures necessary for it to be recognised as such. powers. Whether these influences are to be interpreted as either good or bad is open for debate, but one thing is certain: Methodist missionaries like Rev. William Shaw were vital role players in the unfolding of early settler history in South Africa (Grassow 2008; Millard-Jackson 2008). Methodism also contributed immensely to the fall of apartheid, with many freedom fighters either being Methodists (clergy and laity) or they were shaped through the education facilities established by the Methodist Church in their areas of origin, not even to speak of the struggle of the Methodist Church as an institution against this evil regime.

Methodism is well known in the South African context, especially in the rural areas. It is known for its progressive role in building communities and facilitating processes, which on the one hand exposed injustice, but also served as instruments of communal healing and reconciliation. To this day, every Sunday the South African landscape is coloured with the red blouses of Women's Manyano and the waistcoats of the Young Men's Guild as they celebrate their Methodist heritage, an affiliation many are happy to claim because the MCSA has made a difference in their lives. Many of the stories of the church's contribution to the lives of individuals, families and communities are rooted in the past $^{10}$ and one gets the sense that the Methodist Church of recent years is not as influential as it was in the lives of those who are now among the older generation.

After the fall of apartheid the MCSA's commitment to social change, like that of several denominations, was filled with good intentions but struggled to deliver. Storey (2012:15) credits this general lull in social mission by the Christian Church in South Africa to several factors. Firstly, Church leaders whose theological clarity had been forged in the heat and burden of the struggle were plain weary. Secondly, three of the strongest Church voices of the struggle era were silenced in different ways: one partly muted by being appointed to the chair of the Truth and Reconciliation Commission, another compromised by scandal and jailed for theft and fraud, and a third abdicating his prophetic authority by signing on to Caesar's payroll. Thirdly, many clergy simply bowed out in favour of a newer generation, hoping that they would facilitate transformation (Storey 2012:15).

The Christian Church would have done well and sustained its momentum in social influence if it heeded the voice of Prof. Wiseman Nkuhlu (1995) who called for the Church to engage its new society by doing the following:

- to be the example of peace, racial tolerance, democracy and caring

- to be the instrument of understanding, healing and reconciliation

- to be part of the delivery of social services

- to initiate projects for social and economic development

- to resolve disputes between communities and government

- to fight against crime and corruption

- to assist with the internalising of the values of society's newfound freedom. (p. 7; see also Bentley 2013:266).

10. With this I mean before the transition of power in 1994. 
In a secular democratic constitutional State the Church was afforded this freedom, along with all other religions, to play this pivotal role in social restructuring. More so, it was up to the Church to take initiative in these areas as it was perfectly positioned in society to bring about grass roots change where and when it was needed most (Swart 2009:74). Sadly, it did not take the opportunity with vigour and South African society felt the void left by the Church's initial mission inertia.

This is not to say that the Methodist Church, amongst other denominations, sat back passively. According to Forster (2008):

After the peaceful democratic elections of April 1994 the function and responsibility of the Church had to change from that of a prophetic activism against apartheid, to a role of the reconstruction and development of society. This led to the dawning of a new era, and expression, of social holiness in Southern African Methodism. (p. 432)

Starting off as a floor debate at the MCSA Conference of 1991 (Kumalo 2006:252), The Journey to the New Land Programme was the Church's first official programme to speak directly to its role in a democratic South Africa. The aim of the mission-drive was to strategically play a role in the transition of moving from the 'paradigm of the Exodus from slavery to freedom' (Kumalo 2006:252). It provided the following objectives, which were named the six calls of the MCSA (n.d.):

1. For deepened spirituality for all our people in the life of our Church.

2. That the life and work of the church be directed towards mission rather than maintenance.

3. The rediscovery of every member ministry or the priesthood of all believers.

4. To truly express what it means 'to be one so that the world may believe'.

5. To re-emphasise servant leadership and discernment as our model for leadership and decision-making.

6. To set ordained ministers free for their primary vocation of preaching, teaching and spiritual guidance.

To these six calls were added the Four Imperatives of Mission (MCSA 2008:5):

1. Evangelism and Church Growth - inviting people to personal faith in Christ and His gospel and to belonging in the community of faith as disciples; planting new faith communities especially in informal settlements and new urban multi-cultural congregations.

2. Spirituality - connecting to the life-giving resources of faith that make for moral regeneration and becoming a holy people in the world.

3. Justice and Service - to promote the values of justice, unity and reconciliation and the healing of national ills, physical, environmental and social, and to be Christ's compassionate, outstretched hands to all humanity.

4. Human and Economic Development and Empowerment - the care and growth of children, the plight of the poor, education, quality of life, nation-building.

Kumalo (2006:251) notes that the Programme never fully got off the ground, even though the principles of the Journey to the New Land became subtly engrained in the vision focus of the MCSA (and is still published as the continuing mission call in every yearbook). A second initiative was launched by the Presiding Bishop of the time, Rev. Ivan Abrahams, who called a Mission Congress which convened in 2004 in (what was then called) Umtata. At this gathering, a Mission Charter (Methodist Church of Southern Africa Mission Charter n.d.) was crafted and was formally adopted at the Conference of 2005.

The Mission Charter is a profound theological declaration and set the tone for the MCSA's strategic planning moving forward. Although it is a mission directive that is appropriate for all the countries within which the MCSA serves, it is of particular significance to the South African context. It is a statement which subliminally appreciates the protective environment created by the Constitution, but it obviously pledges its mission to the call of God. The quote from Proverbs 28:19 at the beginning of the Charter poses the Church's recognition of its social responsibility. For the Church, the vision is not only set by the ideals of the constitutions of the countries in which it serves, but states that its vision is divinely inspired. Although the manifesting of this mission will impact on local communities, its horizons are wider: 'A Christ-healed Africa for the healing of the nations.' Another pivotal aspect of the Church's mission is that it is not purely focused on evangelising, but that it clearly stipulates that the role of the church is to act in communities in the Name of Jesus, inspiring social change which brings dignity, healing and transformation.

This is an intentional return to early Wesleyan theology. The impact the Methodist movement had in the 18th and 19th century British context, as well as in North America (particularly pertaining to the abolition of slavery, for instance), is well recognised. Besides the stated examples, the Methodist movement addressed matters such as education, medical care, conditions in prisons, alcoholism, labour conditions and so forth (Bentley 2010:556; Gooch 2006:79). I mention these examples to celebrate the fact that faith communities can make a real difference in the context within which they function. Obviously the British and American contexts are somewhat different to that of South Africa. For one, both Britain and America considered themselves to be countries governed at the time by a Christian ethos, with little space for the influence of other religions. South Africa is a secular constitutional democracy and does not share this one-directional religious emphasis. This does not mean that Christianity's influence should be watered down by any means. For the Church to be in mission, according to the MCSA's Mission Charter, means that the Church needs to be prophetic, not in word only, but in its example and social influence. The question beckons, is the Methodist Church fulfilling its calling as outlined in its Mission Charter?

\section{What is happening in the Methodist Church?}

In order to answer the question of whether the MCSA is fulfilling its Mission Charter directives, thereby making a positive difference in society, it is important to raise the 
issues of agency and of methodology. Le Bruyns (2006:580581) indicates that these are essential considerations in the Church engaging with society.

Christian agency is vested in at least three levels of influence. Firstly, on the structural level the denomination's representation on bodies of national and international influence is reflected. Secondly, at the local level, ministerial leadership and presence provides for the local implementation of the Church's vision. The most important level, and perhaps the most influential, is that of social integration, where the presence and agency of the Church is felt in the influence and ministry of laity in their respective fields of responsibility. The methodology of such engaging suggests a strong theology which breaks down the notion of a separation between what is considered to be personal spirituality and social responsibility.

At a structural level, the Presiding Bishop in partnership with the college of Bishops provide leadership by serving on ecumenical bodies, being the official voice of the MCSA concerning matters that need to be addressed either through the media or directly with offices of power. The Conference of the MCSA also decides on policies and methodologies for the Church to engage with regarding urgent social matters. The wisdom provided by the MCSA Conferences of 2001 until 2012 on the conversation on same-sex relationships, for instance, is one example (Bentley 2012:205-220). Since the incumbent Presiding Bishop, Rev. Ziphozihle Siwa, took office there has been a marked increase in the media statements released by the Office of the Presiding Bishop, ranging from statements on current affairs to that of holding political leadership accountable for their words and actions.

At the local level, the Church's intention starts with the formation of Methodist ministers for the MCSA Connexion. In their training, ministers are formed to recognise the integration between spiritual and social well-being. The newly established Seth Mokitimi Methodist Seminary requires of each minister to complete a twofold programme. The first focuses on Academic Theology. The second, which carries equal weight in the overall assessment, focuses on worship (personal and corporate spirituality), Covenant Discipleship Groups (personal and corporate accountability), Church placements (actively participating in the local church's life and function), Field Education Ministry (participating as volunteers at various organisations and institutions that promote well-being), and Community Life Committees (taking responsibility for the well-being of the seminary community) (Seth Mokitimi Methodist Seminary 2013). It is envisioned that ministers who leave seminary and are deployed throughout the Connexion act as mission agents, well versed in theology, but equally capable of initiating social programmes that address the needs of the communities whom they serve.

One should not underestimate the importance of ministerial agency as ministers who provide sound theological leadership in their communities can lead those communities of faith to become transformational, not only in worship, but affecting change in their places of influence (Bentley 2014:154-155). Agency, influence and integration must always be intentional. Part of this intentionality is for the Church to clearly demonstrate the integration and wholeness it would like to see exist in the world. It would be one thing for instance for the Church to proclaim racial integration in society, but if it does not lead by example this prophetic voice is muted. This particular example leads to the break of credibility in many Christian denominations in South Africa who, despite promoting the notion of racial integration, are structurally divided along racial lines. Although the Methodist Church has some way to go in achieving true racial integration in its worship and service, it is the statement by the MCSA Conference of 1958 declaring the MCSA as 'one and undivided' (MCSA 1959) that has helped the denomination build bridges between people of diverse beliefs and cultures; it also informs its current position on same-sex relationships (MCSA 2008:81).

Besides setting the example for the change the church would like to see, it also has to speak from a credible position. In the Mission Charter, the MCSA places itself in solidarity with the poor. The Church has a responsibility to speak from this position with integrity. For this reason, the MCSA is heeding its own call by making deliberate decisions as to where conferences, conventions and other Church events are to be hosted. In recent times the church has been accused of contradicting itself by virtue of many of these MCSA events being hosted at facilities that do not project the image of a church in solidarity with the poor. But to be in solidarity with the poor is not just about where and how events are hosted. It speaks of the church's identification with the daily struggles that exist in society and addressing these needs to the best of its ability. The voices of the poor are often either ignored or silenced. The church is not only the mouthpiece which amplifies the voices of the marginalised, but can be the instrument which empowers communities to facilitate change (Le Bruyns 2006:585).

In recent years it has been extremely encouraging to see how the MCSA is once again involved in community building projects. Schools are being built, often because government bureaucracy is delaying delivery of education services to communities. ${ }^{11}$ Moreover, clinics are being built, literacy courses are being offered, and Methodist health care professionals are offering their services as part of their tithes to provide consultations to those who cannot afford these services. Methodists in the legal sector are offering legal advice for free, prisons have become places of outreach for local church communities, counselling centres are being

11.This is not only a reality in rural South Africa, but also in urban areas. Despite the influx of 30000 families in the Pretoria East suburbs, the Department of Basic Education does not have any plans to build schools in this area for the foreseeable future. The local Methodist Church, in partnership with a Pentecostal denomination, bult a school which now under the sole leadership of Eastside Community Church will develop into a complete primary school. Many similar projects are taking place around the Connexion. 
established, and community food gardens are being started. The list goes on.

Hopefully by the Church empowering local communities to affect change, it will lead to greater ownership of the freedoms of democracy by society. By this I mean that the thinking that government alone is responsible for delivering services will change into society becoming proactive in bringing about change through service and development. Wesley was convinced that the Church should be an agent of transformation and justice (Storey 2004:44-46). The MCSA has adopted his vision and with its proximity to the poor and its agency through the empowered clergy will for the foreseeable future not only bring about social change in the Name of Jesus, but fulfil its constitutional role in partaking in the building of society for the well-being of all.

Methodism in South Africa has made the following theological contributions. Firstly, regarding soteriology, that the notion of salvation is not to be understood in exclusively spiritual terms. The Church's salvific mission recognises all factors which affect the Christian community's call to love God and to love your neighbour. Social upliftment and the empowering of communities through education and other forms of social service expresses an understanding of a physical form of salvation which is directly connected to the Church's call to work towards the spiritual renewal of society. It needs to be emphasised that the former is not conditional on the achievement of the latter. Salvation is also to be understood as being salvation from structural poverty, from marginalisation, from discrimination, and perhaps most significantly, from oppression. These physical forms of salvation set individuals and communities free to participate more significantly in the public sphere, thereby liberating them to make a greater contribution as citizens in the South African democratic project. So doing, the Church remains faithful to its spiritual commitment by being obedient to its divine calling, but subsequently also becomes a role player in the unfolding of the South African constitutional democracy.

Secondly, Methodism in South Africa adds a renewed perspective to ecclesiology. What is the Church? By committing itself to the Journey to the New Land project, the Mission Charter, through the intentional training of ministers for social change and the deliberate empowering of laity to become instruments of positive change in their everyday contexts, the Church becomes infused in the world, contributing towards the upliftment of society as a whole. This leads to an eschatology which states that the Reign of God is not a supernatural, futuristic event which will end in calamity for the world while citizens of the Kingdom triumph, but that the Reign of God for Christians is witnessed when love and justice become a reality for those from whom it has been withheld. This places the Church in a close relationship with the State. On the one hand, it partners with the State to see that all can enjoy the rights afforded to them by the Constitution; on the other hand, it occupies a prophetic position to speak and act against the powers (even if it stems from the State) which rob people of dignity and life.

\section{Conclusion}

In this article I discussed the place of the Church in the secular democratic constitutional context of South Africa. The thoughts and teaching of Habermas and Forster assisted in locating the role and place of the Church in such a context. The secular democratic constitutional State provides fertile opportunity for the Church to practice its divine calling to love its neighbour. In Wesleyan spirituality the love for one's neighbour is an extension of one's love and worship of God and thus places the Methodist movement in a prime position to facilitate social change. Secondly, I discussed the Mission strategies of the MCSA with particular reference to the Journey to the New Land Programme and the Mission Charter, documents which give credence and focus to Methodists of what it means to be a Church in mission. The Mission Charter emphasises the relationship between spirituality and social responsibility. Lastly, I discussed some of the objectives and the theological understanding of mission employed by the MCSA, which is starting to bear fruit with regard to social transformation. With a higher level of social ownership of its democratic freedom and being guided by God's call to all people to love their neighbour as an act of worship, complete social transformation is indeed possible and probable.

\section{Acknowledgements Competing interests}

The author declares that he has no financial or personal relationship(s) that may have inappropriately influenced him in writing this article.

\section{References}

Bentley, W., 2010, 'The formation of Christian leaders: a Wesleyan approach', Koers - Bulletin for Christian Scholarship 75(3), 551-566. http://dx.doi.org/10.4102/ koers.v75i3.96

Bentley, W., 2012, 'A decade of the same-sex debate in the Methodist Church of Southern Africa (2001-2011)', Studia Historiae Ecclesiasticae 38(suppl.), 205-220.

Bentley, W., 2013, 'Defining Christianity's "prophetic witness" in the post-apartheid South African democracy', Studia Historiae Ecclesiasticae 39(1), 261-273.

Bentley, W., 2014, 'Ministry as Bridge Building: Facilitating culturally diverse faith communities in South Africa', in R.D. Smith, W. Ackah \& A. Reddie (eds.), Churches, blackness, and contested multiculturalism, pp. 145-157, Palgrave Macmillan, New York.

Forster, D.A., 2008, 'Prophetic witness and social action as holiness in the Methodist Church of Southern Africa's mission', Studia Historiae Ecclesiasticae 34(1), 411434

Forster, D.A., 2012, 'God's Kingdom and the transformation of Society', in W. Bentley \& D.A. Forster (eds.), Between Capital and Cathedral: Essays on Church-State relationships, pp. 73-88, Research Institute for Theology and Religion, Pretoria.

Gooch, J.O., 2006, John Wesley for the twenty-first century: set apart for social witness, Discipleship Resources, Nashville.

Grassow, P.S., 2008, 'William Shaw', in W. Bentley \& D.A. Forster (eds.), Methodism in Southern Africa: A celebration of Wesleyan mission, pp. 13-24, AcadSA Publishing, Johannesburg.

Habermas, J. \& Ratzinger, J, 2010, The dialectics of secularization: On Reason and religion, F. Schuller (ed.), Ignatius Press, San Francisco.

Health Systems Trust, 2013, The National health care facilities baseline audit: National summary report, viewed 26 July, 2013 from http://www.doh.gov.za/docs/ reports/2013/Healthcare.pdf

Independent Electoral Commission (IEC), 2014a, 22 April 2009 National election results, viewed 18 July 2014, from http://www.elections.org.za/content/ NPEPublicReports/146/Detailed\%20Results/National.pdf.

Independent Electoral Commission (IEC), 2014b, 2014 National election results, viewed 18 July 2014, from http://www.elections.org.za/content/NPEPublicReports/291/ Results\%20Report/National.pdf.

Kairos Theologians, 1985, Challenge to the Church: A theological comment on the political crisis in South Africa, The Kairos Theologians, Johannesburg. 
Kumalo, S., 2006, 'Transforming South African Methodism: The "Journey to the New Land" programme 1992-1997', Missionalia 34(2), 249-266.

Le Bruyns, C., 2006, 'Ecumenical agencies as partners for development in South Africa', Deel 47(3 /4), 580-587.

Millard-Jackson, J., 2008, 'Who called the tune?', in W. Bentley \& D.A. Forster (eds.) Methodism in Southern Africa: A celebration of Wesleyan mission, pp. 31-39, AcadSA Publishing, Johannesburg.

Nkuhlu, W.L., 1995, 'The Church and socio-economic reconstruction during the transition', in Being Church in a new land: A selection of papers presented at the 1995 National Conference of the South African Council of Churches, pp. 5-8, Edenvale Printers, Johannesburg.

Prozesky, M., 2009, 'Is the secular state the root of our moral problems in South Africa?', Alternation 3, 237-253.

Seth Mokitimi Methodist Seminary, 2013, Our programmes, viewed 15 January 2014 from $\mathrm{http}: / /$ smms1.dyndns.org/index.php/programmes

South Africa, 1996, Constitution of the Republic of South Africa, 1996, Government Printer, Pretoria.

Storey, P.J., 2004, And are we yet alive? Revisioning our Wesleyan heritage in the new Southern Africa, Methodist Publishing House, Cape Town.

Storey, P.J., 2012, 'Banning the flag from our churches: Learning from the Church-State struggle in South Africa', in W. Bentley \& D.A. Forster (eds.), Between capital and cathedral: Essays on Church-State state relationships, pp. 1-20, Research Institute for Theology and Religion, Pretoria.
Swart, I., 2009, 'Meeting the rising expectations? On local churches as organisations of social welfare in South Africa', Journal of Theology for Southern Africa (133), $74-96$.

The Methodist Church of Southern Africa, 1959, Minutes of Conference of the Methodist Church of Southern Africa: 1958, Methodist Publishing House, Cape Town.

The Methodist Church of Southern Africa, 2008, 2008 Yearbook and directory, Methodist Publishing House and Book Depot, Cape Town.

The Methodist Church of Southern Africa n.d., The Journey to a New Land, viewed 01 April 2014, from http://www.methodist.org.za/heritage/journey-to-the-new-land

The Methodist Church of Southern Africa Mission Charter n.d., Mission Charter, viewed 02 April 2014, from http://www.methodist.org.za/heritage/missioncharter.

Theron, P.F., 2008, 'From moral authority to insignificant minority: The precarious state of the Dutch Reformed Church in a post-apartheid South Africa', Journal of Reformed Theology 2(3), 228-239. http://dx.doi.org/10.1163/156973108X333722

Trading Economics n.d., GINI index in South Africa, viewed 25 June 2013, from http:// www.tradingeconomics.com/south-africa/gini-index-wb-data.html

World Bank n.d., GINI index, viewed 23 June 2013, from http://data.worldbank.org/ indicator/SI.POV.GINI

World Economic Forum \& INSEAD, 2013, The global information technology report 2013: Growth and jobs in a hyperconnected world, viewed 26 July 2013, from http://www3.weforum.org/docs/WEF_GITR_Report_2013.pdf 